\title{
Cyclometalated iridium(III) complexes as mitochondria-targeted anticancer agents
}

Kai Xiong, Yu Chen*, Cheng Ouyang, Rui-Lin Guan, Liang-Nian Ji, Hui Chao*

MOE Laboratory of Bioinorganic and Synthetic Chemistry, School of Chemistry and Chemical Engineering, Sun Yat-Sen University, Guangzhou 510275, P. R. China

\begin{abstract}
Four cyclometalated iridium(III) complexes $\left[\operatorname{Ir}(\mathrm{dfppy})_{2}(\mathrm{~L})\right]^{+} \quad(\mathrm{dfppy} \quad=$ 2-(2,4-difluorophenyl)pyridine, $\mathrm{L}=$ 6-(pyridin-2-yl)-1,3,5-triazine-2,4-diamine, Ir1; 6-(isoquinolin-1-yl)-1,3,5-triazine-2,4-diamine, Ir2; 6-(quinolin-2-yl)-1,3,5-triazine-2,4-diamine, Ir3; 6-(isoquinolin-3-yl)-1,3,5-triazine-2,4-diamine, Ir4) have been synthesized and characterized. Distinct from cisplatin, Ir1-Ir4 could specifically target mitochondria and induced apoptosis against various cancer cell lines, especially for cisplatin resistant cells. ICP-MS results indicated that Ir1-Ir4 were taken up via different mechanism for cancer cells and normal cells, which resulted in their high selectivity. The structure-activity relationship and signaling pathways were also discussed.
\end{abstract}

Keywords: Cyclometalated iridium(III) complexes; Mitochondria-targeted; Anticancer; Apoptosis;

\footnotetext{
*Corresponding authors. Fax: +86-20-8411-0613. E-mail: chenyu63@mail.sysu.edu.cn (Y.Chen); ceschh@mail.sysu.edu.cn (H.Chao)
} 


\section{Introduction}

Since the clinical success of cisplatin, carboplatin and oxaliplatin, the therapeutic value of metal-based drugs has long been established [1]. DNA is generally accepted to be the main target of platinum-based anticancer drugs, however, these platinum compounds suffer from two main disadvantages: they are inefficient against platinum-resistant tumors, and they have severe side effects such as neurotoxicity, kidney problems and allergic reactions. These drawbacks have also stimulated the development of non-platinum metal-based therapeutics [2-4].

Organometallic iridium complexes have recently been found to be alternatives to platinum-based anticancer agents because of their rich synthetic chemistry, variable oxidation states that are accessible under physiological conditions and kinetically stable [5-6]. Moreover, their multiple mechanisms of anticancer action may be distinct from those of platinum-based drugs. Meggers and co-workers investigated the binding of iridium to pyridocarbazole, which are known to be a ATP competitive inhibitor that targets the ATP-binding site of protein kinases [7]. Serum albumin is another target of anticancer iridium compounds that reported by Lo and co-workers [8]. Indole derivative, which is known to bind to BSA, was introduced into iridium complexes and were found to be highly cytotoxic toward HeLa cells. In addition to protein, various organometallic iridium have been found to bind DNA through intercalation or to form DNA-Ir adducts [9]. Interestingly, most organometallic ligands of the reported iridium anticancer complexes are metallocenes [10-12], half-sandwich [13-15], carbene- [16], CO- [17], or $\pi$-ligands [18]. Traditional cyclometalated polypyridyl-like ligands (CNN) have attracted 
much less attention.

As one of the most important cell signaling center, mitochondria are essential organelles required for cellular energy production and are involved in many other cellular activities, one of which is to produce reactive oxygen species (ROS) and leads to mitochondria-mediated apoptosis [19-21]. Our previous works showed that mitochondria is the main target of cyclometalated iridium(III) complexes [22-27]. Herein, four novel cyclometalated iridium(III) complexes were developed as mitochondria-targeted theranostic agents. The mitochondria-specific target, cellular uptake and antitumor activity, as well as cell-cycle arrest and apoptosis signaling pathways were studied. The unique structure and characteristic of Ir(III) complex designed in this investigation may contribute to the future development of improved chemotherapeutics.

\section{Experimental}

\subsection{Materials and measurements}

All reagents were purchased from commercial sources and used without further purification unless otherwise specified. Chromatographic separations were performed on neutral aluminum oxide. All solvents were of analytical grade. All buffer components were of biological grade and used as received. $\operatorname{IrCl}_{3} \cdot 3 \mathrm{H}_{2} \mathrm{O}$, 2-(2,4-difluorophenyl)pyridine （dfppy), 2-ethoxyethanol, 2-cyano-pyridine, isoquinoline-1-carbonitrile, 2-cyanoquinoline, isoquinoline-3-carbonitrile and dicyandiamide were purchased from Sigma Aldrich and were used without further purification. Four ligands, 6-pyridyl-1,3,5-triazine-2,4-diamine (PyTNH), 
6-(isoquinolin-1-yl)-1,3,5-triazine-2,4-diamine (1-IQTNH), 6-(quinolin-2-yl)-1,3,5-triazine-2,4-diamine (2-QTNH) and 6-(isoquinolin-3-yl)-1,3,5-triazine-2,4-diamine (3-IQTNH) were prepared according to our previously reported methods [28-29]. All the complexes were dissolved in DMSO immediately preceding the experiments; the calculated quantities of the drug solutions were then added to the appropriate medium to yield a final DMSO concentration of less than $1 \%(\mathrm{v} / \mathrm{v})$.

Microanalysis (C, H, and N) was carried out using a Perkin-Elmer 240Q elemental analyzer. Electrospray mass spectra (ESI-MS) were recorded on a LCQ system (Finnigan MAT, USA). The expected and measured isotope distributions were compared. The ${ }^{1} \mathrm{H}$ NMR spectra were recorded on a Bruker AVANCE 400 spectrometer (400 MHz). All chemical shifts are reported relative to tetramethylsilane (TMS).

\subsection{Synthesis of the iridium(III) complexes Ir1-Ir4}

The complexes Ir1-Ir4 were synthesized in a similar manner to previously reported methods [22-23]. Briefly, a mixture of 2-ethoxyethanol and water (3:1, v/v) was added to a flask containing $\mathrm{IrCl}_{3} \cdot 3 \mathrm{H}_{2} \mathrm{O}(1.0 \mathrm{mmol})$ and the cyclometalated ligand dfppy (2.5 mmol). The mixture was refluxed for $24 \mathrm{~h}$. After cooling, the yellow precipitate was filtered to give crude cyclometalated Ir(III) chloro-bridged dimer [30]. The chloro-bridged dimer (0.20 mmol) and four ligands (PyTNH, 1-IQTNH, 2-QTNH and 3-IQTNH, $0.4 \mathrm{mmol}$ respectively) were placed in a $100 \mathrm{~mL}$ round bottomed flask with $48 \mathrm{~mL}$ of methanol and dichloromethane $(3: 1, \mathrm{v} / \mathrm{v})$. The mixture was heated at $65^{\circ} \mathrm{C}$ for $8 \mathrm{~h}$ under argon. The solution was filtered, and the precipitate was washed three times $(2 \mathrm{~mL})$ with methanol. 
The filtrate and washings were combined and reduced by evaporation to a volume of $1 \mathrm{~mL}$. The product was purified by column chromatography on alumina using acetonitrile as the eluant (yield: $62-74 \%$ ). Then, the iridium complexes were further characterized by elemental analysis, ${ }^{1} \mathrm{H}$ NMR and ESI-MS measurements. The structural parameters of Ir4 are described in detail in the Supporting Information.

Ir1. Yield: $73 \%$. ${ }^{1} \mathrm{H}$ NMR (400 MHz, DMSO-d 6 ) $\delta 8.58$ (d, $\left.J=7.7 \mathrm{~Hz}, 1 \mathrm{H}\right), 8.47$ (dd, $J$ $=5.8,0.8 \mathrm{~Hz}, 1 \mathrm{H}), 8.36(\mathrm{dd}, J=4.3,2.4 \mathrm{~Hz}, 1 \mathrm{H}), 8.35-8.32(\mathrm{~m}, 1 \mathrm{H}), 8.30(\mathrm{~d}, J=8.5 \mathrm{~Hz}$, 1H), 8.15 - 8.06 (m, 2H), 8.01 (s, 1H), 7.94 (s, 1H), 7.91 (s, 1H), 7.80 (m, 1H), 7.79 7.75 (m, 1H), 7.62 (dd, $J=5.8,0.8 \mathrm{~Hz}, 1 \mathrm{H}), 7.40$ (m, 1H), 7.35 (m, 1H), 7.00 (m, 2H), 5.64 (dd, $J=8.2,2.3 \mathrm{~Hz}, 1 \mathrm{H}), 5.46$ (dd, $J=8.4,2.3 \mathrm{~Hz}, 1 \mathrm{H}), 4.97$ (s, 1H). ESI-MS: m/z = 760.80 ([M-Cl$\left.]^{+}\right)$. Elemental Analysis: Anal. Calcd. for $\mathrm{C}_{30} \mathrm{H}_{20} \mathrm{ClF}_{4} \operatorname{IrN}_{7}(\%)$ : C, 45.26, H, 2.53, N, 14.07; found(\%): C, 45.17, H, 2.44, N, 14.15.

Ir2. Yield: 67\%. ${ }^{1} \mathrm{H}$ NMR (400 MHz, DMSO-d 6 ) $\delta 10.51(\mathrm{~d}, J=8.8 \mathrm{~Hz}, 1 \mathrm{H}), 8.54$ (dd, $J=5.8,0.8 \mathrm{~Hz}, 1 \mathrm{H}), 8.37$ (d, $J=8.5 \mathrm{~Hz}, 1 \mathrm{H}), 8.29$ (d, $J=8.2 \mathrm{~Hz}, 2 \mathrm{H}), 8.18$ (d, $J=6.1 \mathrm{~Hz}$, 1H), $8.17-8.09$ (m, 2H), 8.05 (d, $J=8.9 \mathrm{~Hz}, 1 \mathrm{H}), 8.02$ (d, $J=1.2 \mathrm{~Hz}, 1 \mathrm{H}), 8.00$ (d, $J=$ $1.2 \mathrm{~Hz}, 1 \mathrm{H}), 7.99-7.95$ (m, 1H), $7.95-7.90$ (m, 1H), 7.81 (m, 1H), 7.73 (t, $J=5.9 \mathrm{~Hz}$, 1H), 7.34 (m, 1H), 7.29 (m, 1H), 7.05 - 6.95 (m, 2H), 5.62 (m, 1H), 5.50 (m, 1H), 5.16 (s, 1H). ESI-MS: $\mathrm{m} / \mathrm{z}=810.90\left(\left[\mathrm{M}-\mathrm{Cl}^{-}\right]^{+}\right)$. Elemental Analysis: Anal. Calcd. for $\mathrm{C}_{34} \mathrm{H}_{22} \mathrm{ClF}_{4} \mathrm{IrN}_{8}(\%)$ : C, 50.37, H, 2.74, N, 13.82; found(\%): C, 50.29, H, 2.64, N, 13.77.

Ir3. Yield: 62\%. ${ }^{1} \mathrm{H}$ NMR (400 MHz, DMSO-d 6 ) $\delta 8.93(\mathrm{~d}, J=8.7 \mathrm{~Hz}, 1 \mathrm{H}), 8.70(\mathrm{~d}, J=$ $8.6 \mathrm{~Hz}, 1 \mathrm{H}), 8.48$ (d, $J=5.7 \mathrm{~Hz}, 1 \mathrm{H}), 8.43$ (d, $J=8.5 \mathrm{~Hz}, 1 \mathrm{H}), 8.15$ (d, $J=8.5 \mathrm{~Hz}, 2 \mathrm{H})$, 8.12 (dd, $J=8.9,4.6 \mathrm{~Hz}, 1 \mathrm{H}), 8.08$ (d, $J=5.9 \mathrm{~Hz}, 2 \mathrm{H}), 7.98$ (s, 1H), $7.97-7.93$ (m, 1H), 
7.88 (s, 1H), 7.72 (d, $J=9.0 \mathrm{~Hz}, 1 \mathrm{H}), 7.67$ (dd, $J=11.5,4.3 \mathrm{~Hz}, 1 \mathrm{H}), 7.38$ (m, 1H), $7.34-$ $7.31(\mathrm{~m}, 1 \mathrm{H}), 7.31-7.28(\mathrm{~m}, 1 \mathrm{H}), 7.12-7.04(\mathrm{~m}, 1 \mathrm{H}), 7.01-6.93(\mathrm{~m}, 1 \mathrm{H}), 5.65$ (dd, $J=$ 8.5, $2.3 \mathrm{~Hz}, 1 \mathrm{H}$ ), 5.61 (dd, $J=8.3,2.3 \mathrm{~Hz}, 1 \mathrm{H}), 4.92$ (s, 1H). ESI-MS: m/z = 810.85 $\left(\left[\mathrm{M}-\mathrm{Cl}^{-}\right]^{+}\right)$. Anal. Calcd. for $\mathrm{C}_{34} \mathrm{H}_{22} \mathrm{ClF}_{4} \mathrm{IrN}_{8}(\%)$ : C, 50.37, H, 2.74, N, 13.82; found(\%): C, 50.41, H, 2.80, N, 13.75 .

Ir4. Yield: $74 \% .{ }^{1} \mathrm{H}$ NMR (400 MHz, DMSO-d 6 ) $\delta 9.14(\mathrm{~s}, 1 \mathrm{H}), 8.51(\mathrm{dd}, J=5.8,0.8$ Hz, 1H), 8.46 (s, 1H), 8.37 (dd, $J=8.2,5.1 \mathrm{~Hz}, 2 \mathrm{H}), 8.30$ (d, $J=8.5 \mathrm{~Hz}, 1 \mathrm{H}), 8.20$ (d, $J=$ $8.0 \mathrm{~Hz}, 1 \mathrm{H}), 8.11$ (t, $J=7.7 \mathrm{~Hz}, 1 \mathrm{H}), 8.08-8.05$ (m, 1H), $8.05-8.02$ (m, 1H), $7.95-7.84$ (m, 4H), $7.77-7.72(\mathrm{~m}, 1 \mathrm{H}), 7.37(\mathrm{~m}, 1 \mathrm{H}), 7.26(\mathrm{~m}, 1 \mathrm{H}), 7.07-6.97$ (m, 2H), $5.69-5.60$ (m, 1H), 5.52 (dd, $J=8.3,2.3 \mathrm{~Hz}, 1 \mathrm{H}), 5.04$ (s, 1H). ESI-MS: m/z = $810.80\left(\left[\mathrm{M}-\mathrm{Cl}^{-}\right]^{+}\right.$). Anal. Calcd. for $\mathrm{C}_{34} \mathrm{H}_{22} \mathrm{ClF}_{4} \mathrm{IrN}_{8}(\%)$ : C, 50.37, H, 2.74, N, 13.82; found(\%): C, 50.33, H, 2.69, N, 13.79.

\subsection{X-Ray crystallography}

Single crystals of the complex Ir3 suitable for an X-ray crystallographic study were grown from acetonitrile-toluene $(1: 1, \mathrm{v} / \mathrm{v})$ at room temperature. A yellow crystal with the dimensions $0.12 \times 0.1 \times 0.09 \mathrm{~mm}^{3}$ was recorded on a Rigaku R-AXIS SPIDER IP diffractometer (MoK $\alpha, \lambda=0.71073 \AA$ ) at 293(2) K. An absorption correction was applied with the SADABS program [31]. The structure solution and full-matrix least-squares refinement based on F2 for Ir3 were performed with the SHELXS 97 and SHELXL 9734 program packages, respectively [32]. All the non-hydrogen atoms were refined anisotropically. Hydrogen atoms of the organic ligands were generated geometrically 
(C-H $0.96 \AA$ ). Detailed crystallographic data for the crystal structural analysis have been deposited with the Cambridge Crystallographic Data Centre (1448028) contains the supplementary crystallographic data for the present paper.

\subsection{Cell Culture Conditions and in vitro Cytotoxicity Assay}

MCF-7, NCI-H460, HepG2, Bel-7402, L-02, HeLa and HCT-116 cells were maintained as monolayer cultures in DMEM. The A549 and A549R cells were maintained in RPMI 1640. Exponentially growing cells were seeded in triplicate into 96 -well plates at $1 \times 10^{4}$ cells/well. After incubation for $24 \mathrm{~h}$, the cells were treated with increasing concentrations of the tested complexes for $48 \mathrm{~h}$. The in vitro cytotoxicity assay was performed by using the MTS kit following the manufacturer's protocol (Promega, WI, US). The absorbance of the samples was measured at $490 \mathrm{~nm}$ in an ELISA reader (BioTek Instruments, Winooski, VT).

\subsection{Cellular uptake and the degree of localization}

For uptake studies, exponentially growing A549R and LO2 cells were harvested, and the resulting single-cell suspension was plated in $100 \mathrm{~mm}$ tissue culture plates (Costar) at $1 \times 10^{6}$ cells/plate. After $24 \mathrm{~h}$ at $37{ }^{\circ} \mathrm{C}$, the cells were incubated with $2.5 \mu \mathrm{M} \operatorname{Ir}(\mathrm{III})$ complexes for $6 \mathrm{~h}$ at $37^{\circ} \mathrm{C}$. The cells were rinsed with PBS, detached with trypsin, counted and divided into two portions. In the first portion, the cells were keep integrity; in the second portion, the mitochondrial was extracted using a mitochondrial extraction kit (Pierce, Thermo). All samples were digested in $60 \% \mathrm{HNO}_{3}$ at room temperature for $24 \mathrm{~h}$. 
Each sample was then diluted with doubly-distilled water to obtain $2 \% \mathrm{HNO}_{3}$ sample solutions [33]. The iridium concentrations in the two portions were determined by ICP-MS (Thermo Elemental Co., Ltd.). Data are reported as the mean \pm standard deviation $(n=3)$.

\subsection{Temperature and inhibitor studies [34]}

A549R cells were detached from the culture and were preincubated with $50 \mathrm{mM}$ 2-deoxy-D-glucose and $5 \mu \mathrm{M}$ oligomycin in serum-free DMEM for $1 \mathrm{~h}$ before incubation of $2.5 \mu \mathrm{M}$ Ir1-Ir4 with inhibitor in the fresh media for $6 \mathrm{~h}$ at $4{ }^{\circ} \mathrm{C}$ or $37{ }^{\circ} \mathrm{C}$. The cells were washed with PBS solution and then trypsinized and processed for ICP-MS analysis.

\subsection{Cell cycle and Annexin-V analysis}

After treated with Ir1-Ir4 $(2.5 \mu \mathrm{M})$ for $24 \mathrm{~h}$, A549R cells were harvested and centrifuged (10 min at $800 \mathrm{~g}$ ) and fixed in $2 \mathrm{~mL}$ of $70 \%$ aqueous ethanol (v/v). After an incubation period of at least $12 \mathrm{~h}$ at -20

ICatco a g)eamdentrifuged (10 washed twice with ice-cold PBS. The cells were re-suspended in $200 \mu \mathrm{L}$ staining solution containing PI $(10 \mu \mathrm{g} / \mathrm{mL})$ and DNase-free RNase $(100 \mu \mathrm{g} / \mathrm{mL})$ and analyzed by a BD FACSCalibur $^{\mathrm{TM}}$ cytometer (Becton Dickinson, Heidelberg, Germany). The number of cells analyzed for each sample was 10000 , and the experiments were repeated at least three times under identical conditions. Data were collected by BD CellQuest ${ }^{\mathrm{TM}}$ Pro software and analyzed by ModFit LT 2.0 software.

Annexin $\mathrm{V}$ and propidium iodide (PI) co-staining of the apoptotic membranes was 
performed by using the annexin V-FITC apoptosis detection kit following the manufacturer's protocol (Shanghai Sangon Biological Engineering Technology \& Services Co. Ltd.). A549R cells seeded into 35 mm glass-bottom dishes (Corning) were treated with Ir1-Ir4 $(2.5 \mu \mathrm{M})$ for $24 \mathrm{~h}$. After washed twice with PBS, the cells were stained with annexin V-FITC for 10 min. Cells were washed twice with PBS and then were stained with PI and measured by a BD FACSCalibur ${ }^{\mathrm{TM}}$ cytometer with an excitation wavelength of $488 \mathrm{~nm}$ and an emission wavelength of $530 \pm 20 \mathrm{~nm}$ and $610 \pm 20 \mathrm{~nm}$. Annexin-V positive cells were considered apoptotic.

\subsection{Analysis of mitochondrial membrane potential}

Mitochondrial dysfunction was determined by measuring changes in the mitochondrial membrane potential (MMP, $\Delta \Psi \mathrm{m})$ using an inverted fluorescence microscope and flow $\begin{array}{llllll}\text { cytometry after } & \text { staining } & \text { live } & \text { cells } & \text { with } & \text { JC-1 }\end{array}$ (5,5',6,6'-tetrachloro-1,1',3,3'-tetrethylbenzimidalylcarbocyanine iodide) [35]. A549R cells were treated with $2.5 \mu \mathrm{M}$ Ir1-Ir4 for 24 h. For flow cytometry analysis, A549R cells were re-suspended at $1 \times 10^{6} / \mathrm{mL}$ in pre-warmed JC- 1 working buffer containing $5 \mu \mathrm{g} / \mathrm{mL}$ JC- 1 and incubated for $15 \mathrm{~min}$ in a $37{ }^{\circ} \mathrm{C}, 5 \% \mathrm{CO}_{2}$ incubator. Subsequently, the cells were

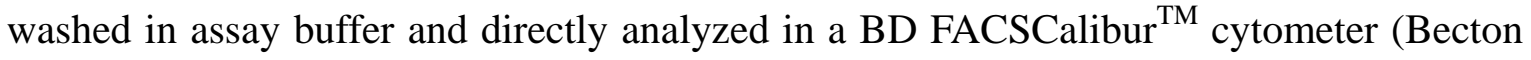
Dickinson, Heidelberg, Germany). Photomultiplier settings were adjusted to detect JC-1 monomer fluorescence signals on the FL1 detector (green fluorescence, centered around $525 \mathrm{~nm}$ ) and JC-1 aggregate fluorescence signals on the FL2 detector (red fluorescence, centered around $590 \mathrm{~nm}$ ). The relative monomer (green) fluorescence intensity values 
were used for data presentation.

\subsection{Caspase -3/7 and caspase 9 activities assay}

A549R cells were treated with Ir1-Ir4 $(2.5 \mu \mathrm{M})$ for $24 \mathrm{~h}$, and the caspase $-3 / 7$ and caspase 9 activities were determined using the Caspase-Glo assay (Promega, WI, US) according to the manufacturer's instructions [4].

\subsection{Intracellular reactive oxygen species (ROS) measurement}

After treatment with $2.5 \mu \mathrm{M}$ Ir1-Ir4 for 24 h, A549R cells were incubated with $10 \mu \mathrm{M}$ DCFH-DA (Sigma-Aldrich) for $20 \mathrm{~min}$ at $37^{\circ} \mathrm{C}$ [36]. The fluorescence intensity of cells was measured by flow cytometry (Becton Dickinson, Franklin Lakes, NJ), confocal microscope (Leica Microsystems, Wetzlar, Germany), and microplate analyzer (Infinite M200, TECAN, Switzerland) with excitation set at $488 \mathrm{~nm}$ and emission at $530 \pm 20 \mathrm{~nm}$. For ROS inhibitors assay, Tiron (5 mM) and NAC (10 mM) were applied $1 \mathrm{~h}$ before Ir1-Ir4 $(2.5 \mu \mathrm{M})$ treatment and kept in the medium during Ir1-Ir4 treatment until the cells were analyzed.

\section{Results and discussion}

\subsection{Synthesis and characterization}

It is known that diamino-1,3,5-triazines are a class of compounds possessing diverse bioactivities such as anticancer, anti-inflammation, anti-allergy and offering a protective effect against gastric lesions [37-41]. 2,4-diamino-1,3,5-triazine derivatives were easily 
prepared following the method established by Case [42]. The preparations of the Ir1-Ir4 (Fig. 1) complexes were carried out through bridge splitting reactions of the dinuclear precursors $\left[\operatorname{Ir}(\mathrm{dfppy}){ }_{2} \mathrm{Cl}\right]_{2}$ with the 2,4-diamino-1,3,5-triazine ligands in a stoichiometric amount [22]. The synthesized complexes were characterized with ESI-MS, elemental analysis and ${ }^{1}$ H NMR spectroscopy (Fig. S1-S4 in Supplementary Information).

The molecular structures of Ir3 was also confirmed by single-crystal X-ray diffraction analysis (Fig. 2). The crystal data and structural refinements are shown in Table S1. Selected bond lengths and angles are presented in Table S2. The coordination of the iridium atom of Ir3 is distorted octahedral, with the largest deviation observed in the bite angle $\left(75.23^{\circ}\right)$ of the 2,4-diamino-1,3,5-triazine derivative ligand (Table S2). The cyclometalated $\mathrm{C}$ atoms of the dfppy ligands are in a mutually cis arrangement, and their high trans influence leads to Ir-N (2-QTNH) distances (2.194(2) $\AA$ ), which are longer than the corresponding distances (2.006(5) $\AA$ ) in the cyclometalated ligand [43].

\subsection{In vitro cytotoxicity}

To explore the antitumor potential of Ir1-Ir4, a panel of cell lines representing a range of tumor types, including MCF-7, NCI-H460, HepG2, Bel-7402, L-02, HeLa, HCT-116, A549 and A549R (cisplatin-resistant A549 cells) was treated with various concentrations of Ir1-Ir4 or cisplatin (positive control) for 48 h. As human normal cells, LO2 was set as the control group. In vitro cytotoxicity experiment were performed by using the MTS kit following the manufacturer's protocol. The resulting $\mathrm{IC}_{50}$ values for the tested compounds are shown in Table 1. Ir1 exhibited a broad spectrum of inhibition on various human 
cancer cells, with $\mathrm{IC}_{50}$ values ranging from 8.68 to $19.0 \mu \mathrm{M}$, which were comparable with those of cisplatin $\left(\mathrm{IC}_{50}=14.7 \sim 87.2 \mu \mathrm{M}\right.$ ), indicating cytotoxic effects on cancer cells. As isomers, Ir2 and $\mathbf{I r} \mathbf{3}$ possessed similar $\mathrm{IC}_{50}$ values and were more potent than Ir1 against all cancer cells screened. Interestingly, unexpected excellent anticancer properties for Ir4 were observed. HeLa cells was especially susceptible to $\mathbf{I r 4}$, with a lower $\mathrm{IC}_{50}(0.86 \mu \mathrm{M})$ than that of Ir2 $(6.44 \mu \mathrm{M})$ and $\operatorname{Ir} 3(5.96 \mu \mathrm{M})$, although Ir4 is the isomer of Ir2 and Ir3 as well. In addition, all iridium complexes were sensitized to cisplatin-resistance cancer cells A549R, implying the existence of different anticancer mechanism. Therefore, A549R cells were selected for further researches.

Possessing selectivity between human cancer and normal cells is important in developing cancer chemotherapy. As shown in Table 1, the $\mathrm{IC}_{50}$ values of Ir1-Ir3 in LO2 cells were 47.2 $\pm 3.2,40.2 \pm 4.1$ and $38.6 \pm 2.8 \mu \mathrm{M}$, higher than those of cancer cells and similar with that of cisplatin $(46.4 \pm 4.8 \mu \mathrm{M})$. Analogous phenomenon was observed for Ir4. It should be pointed out that, despite Ir4 exhibited much higher cytotoxicity in cancer cell lines than Ir1-Ir3, their $\mathrm{IC}_{50}$ value for normal cells were similar.

\subsection{Cellular uptake and the degree of localization}

As reported, the cytotoxicity of transition metal-based anticancer drugs are dramatically influenced by their cellular uptake [44]. Therefore, the difference of in vitro cytotoxic activity for Ir1-Ir4, as well as the selectivity between cancer cells and normal cells, indicated that the cellular uptake of Ir1-Ir4 may be different. The uptake of Ir1-Ir4 by the A549R cells and LO2 cells were quantified by ICP-MS. Cells were 
incubated with $2.5 \mu \mathrm{M}$ of Ir1-Ir4 for $6 \mathrm{~h}$, and excess dye was washed away by the buffer solution. Four iridium(III) complexes could cross the cellular membranes to eventually reach the inside of the cell. ICP-MS measurements of the Ir1-Ir4 content gave $7.63 \pm$ 0.42, $8.23 \pm 0.60,8.06 \pm 0.38$ and $7.87 \pm 0.54 \mathrm{fg} /$ cell for A549R cells, while those were $2.38 \pm 0.30,2.96 \pm 0.24,2.82 \pm 0.27$ and $3.02 \pm 0.15$ fg/cell for LO2 cells (Fig. 3) indicated that the cellular uptake mechanism may be different.

The key factors involved in iridium(III) complex Ir1-Ir4 internalization were investigated in detail to further confirm our speculate. Generally speaking, small molecules can be uptake through energy-dependent (endocytosis, active transport) and energy-independent (passive diffusion) pathways. As shown in Fig. 4, low temperature (4 ${ }^{\circ} \mathrm{C}$ ) incubation led to inhibition of cellular uptake by $37 \%, 40 \%, 36 \%$ and $33 \%$ for A549R cells, but shown little influence on LO2 cells. This interesting result indicated that energy-independent pathway, such as passive diffusion, is the cellular uptake mechanism for LO2 cells but is not involved in that of A549R cells. This conclusion was further support by metabolic inhibition results. Cells were pretreated with two metabolic inhibitors, oligomycin and 2-deoxy-D-glucose, which deplete the cell's energy and diminish energy-dependent uptake, and then were incubated with $2.5 \mu \mathrm{M}$ of Ir1-Ir4. As determined by ICP-MS (Fig. 4), when active transport was inhibited, the intracellular iridium amount for A549R cells was significantly suppressed but had no effect on LO2 cells.

The distribution of localization characteristics is another key point that influences the cytotoxicity effect [45-46]. Out of expect, no significant difference was observed in the 
specificity to mitochondria between these four iridium complexes. For A549R cells, the ratio $I_{\text {mito/cell }}$ between the mitochondria and whole cell was $85.3 \%, 86.2 \%, 82.7 \%$ and 88.1\%. Similar results are observed for LO2 cells and the $I_{\text {mito/cell }}$ was $87.7 \%$, $84.6 \%$, 85.4\% and $85.3 \%$, respectively. This result is not consistent with the MTS experiment that Ir4 possessed the highest in vitro cytotoxicity. Thus, we speculated that there were some unknown interactions between Ir4 and mitochondria.

\subsection{Apoptosis and cell cycle arrest}

It is known that the externalization of the phosphatidylserine membrane is the characteristics of cells undergoing apoptosis [47]. Annexin-V/PI staining experiment was performed. In contrast to vehicle-treated cells, after treatment with $\operatorname{Ir1-Ir4~(2.5~} \mu \mathrm{M})$ for $24 \mathrm{~h}$, the percentage of A549R cells stained positive for annexin-V was $11.8 \pm 0.6 \%, 12.2$ $\pm 1.1 \%, 14.7 \pm 0.8 \%$ and $21.7 \pm 1.8 \%$, respectively (Fig. 5a). This result consists with the in vitro cytotoxicity.

Because cell cycle arrest phenomenon has been observed in various metal-based anticancer complexes induced cell apoptosis, therefore, the effect of Ir1-Ir4 on the cell cycle was also investigated. Fig. 5b shown that exposure of the A549R cells to $2.5 \mu \mathrm{M}$ Ir1-Ir4 for $24 \mathrm{~h}$ resulted in marked increase in the proportion of apoptotic cells as reflected by the sub-diploid peak. The values of sub-G1 varied from $6.7 \%$ to as high as 27.5\%, which consisted with the in vitro cytotoxicity. However, it is interesting that the cell cycle arrest induced by Ir1-Ir4 were not significant. The proportion of cell cycle varied irregularly. For example, the value of G0/G1 was $54.2 \%$ for the control cells, and 
this proportion reduced to $48.5 \%$ and $41.9 \%$ for Ir1-Ir2, but increased to $58.7 \%$ for $\mathbf{I r} 3$ and $62.3 \%$ for Ir4. In addition, the percent of G2 period was $17.8 \%, 22.6 \%, 25.0 \%, 21.1 \%$ and $9.8 \%$ for control and Ir1-Ir4 group, respectively. These results indicate that the anti-proliferative activities of the Ir1-Ir4 were mainly caused by apoptosis rather than cell cycle arrest [48-50].

\subsection{The induction of mitochondrial dysfunction}

Due to the fact that mitochondrial dysfunction is involved in cell apoptotic death. Mitochondrial dysfunction induced by Ir1-Ir4 was determined by measuring changes in the mitochondrial membrane potential (MMP, $\Delta \Psi_{\mathrm{m}}$ ). JC-1 is cationic dyes that exhibit potential-dependent accumulation in mitochondria. Mitochondrial depolarization is indicated by a decrease in the red $(\sim 590 \mathrm{~nm}) /$ green $(\sim 525 \mathrm{~nm})$ fluorescence intensity ratio. The representative JC-1 red/green signal ratios recorded by flow cytometry (Fig. 6). After $24 \mathrm{~h}$ of incubation, treatment with $2.5 \mu \mathrm{M}$ Ir1-Ir4 decreased the JC-1 red/green signal ratio from $31.2 \pm 2.0$ (control) to $12.6 \pm 0.8,1.58 \pm 0.2,1.41 \pm 0.1$ and $0.32 \pm 0.1$, respectively.

The loss of MMP was also evidenced by the activities of caspase- 9 and caspase-3/7. When mitochondrial membrane permeability transition, cytochrome $c$ may be released from mitochondria and induced the activating of caspase 9, then subsequently initiates a caspase cascade involving caspase-3. caspase-3 is known to be the biochemical hallmark of both early and late-stage apoptosis. Treated with $2.5 \mu \mathrm{M}$ Ir1-Ir4 for $24 \mathrm{~h}$, the activities of caspase- 9 and caspase-3/7 were detected using the Caspase-Glo assay kit (Promega, 
US). As shown in Fig. 7a, significant increases in the activities of caspase-9 and caspase-3/7 were observed. Possessing the best in vitro anti-proliferative activity, the treatment of Ir4 resulted in a 5.4-fold and 6.2-fold increase in the fluorescence signal for caspase- 9 and caspase-3/7 when compared with control.

\subsection{Intracellular reactive oxygen species (ROS) accumulation}

Induced ROS accumulation is one of the important characters that involved in various metal-based anticancer complexes. ROS accumulation was quantified by the DCFH-DA (2',7'-dichlorofluorescein-diacetate) staining. DCFH-DA can be oxidized by the presence of endogenously generated ROS and release the fluorophore 2',7'-dichlorofluorescein (DCF). Treatment with $2.5 \mu \mathrm{M}$ Ir1-Ir4 for 24 h resulted in a 4.4, 5.1, 5.6 and 7.8 fold increase in the fluorescence signal compared with control (Fig. 7a). To further examine the role of ROS generation in Ir1-Ir4 induced apoptotic cell death, the effects of two ROS scavengers, tiron (4,5-dihydroxy-1,3- benzenedisulfonic acid disodium salt) and NAC (N-acetylcysteine), on Ir1-Ir4 induced apoptosis were investigated. Tiron and NAC was nontoxic at the tested concentrations for A549R. The presence of either tiron or NAC significantly suppressed the Ir1-Ir4 induced apoptosis as demonstrated by the drastic decrease in Annexin-V positive labeling (Fig. 7b).

\section{Conclusions}

Four cyclometalated iridium(III) complexes with 2,4-diamino-1,3,5-triazine derivatives (Ir1-Ir4) were successfully developed as novel anticancer agent. In vitro cytotoxicity 
experiments demonstrated that in addition to possessing higher cytotoxic potency than the widely used clinical chemotherapeutic agent cisplatin, Ir1-Ir4 exhibited high selectivity between tumor cells and normal cells. This essential selectivity for developing anticancer drugs is resulted from the different mechanisms of entering tumor cells and normal cells. As evidenced by ICP-MS, energy-independent pathway is the cellular uptake mechanism for LO2 cells while Ir1-Ir4 were taken up by A549R cells via energy-dependent pathway. Moreover, the intracellular iridium amounts as well as the distribution of localization of Ir1-Ir4 in A549R were similar. Interestingly, Ir4 shows much more potential than Ir2 and Ir3, even though they are isomers. Therefore, some unknown interactions between Ir4 and mitochondria are suggested and further study is required. Signaling pathways analysis demonstrated that these complexes induced apoptosis via the mitochondrial pathway. Treatment of A549R cells with Ir1-Ir4 could result in generation of ROS, prominent depletion of $\Delta \Psi_{\mathrm{m}}$ and activation of Caspase 9 and Caspase 3/7. We hope that these results will prove of value in further understanding the cellular uptake of iridium complexes and may contribute to the future development of improved chemo-therapeutics against human cancers.

\section{Acknowledgements}

This work was supported by the 973 Program (No. 2015CB856301), the National Science Foundation of China (Nos. 21171177, 21471164, 21501201), and the Fundamental Research Funds for the Central Universities (No. 15lgpy03). 


\section{Appendix A. Supplementary data}

Supplementary data to this article can be found online at .

\section{References}

[1] Z. Liu, A. Habtemariam, A.M. Pizarro, S.A. Fletcher, A. Kisova, O. Vrana, L. Salassa, P.C.A. Bruijnincx, G.J. Clarkson, V. Brabec, P.J. Sadler, Organometallic half-sandwich iridium anticancer complexes, J. Med. Chem., 54 (2011), 3011-3026.

[2] D.L. Ma, D.S.H. Chan, C.H. Leung, Group 9 organometallic compounds for therapeutic and bioanalytical applications, Acc. Chem. Res., 47 (2014), 3614-3631.

[3] N. Muhammad, Z.J. Guo, Metal-based anticancer chemotherapeutic agents, Curr. Opin. Chem. Biol., 19 (2014) 144-153.

[4] Y. Chen, M.Y. Qin, L. Wang, H. Chao, L.N. Ji, A.L. Xu, A ruthenium(II) $\beta$-carboline complex induced p53-mediated apoptosis in cancer cells, Biochimie, 95 (2013), 2050-2059.

[5] G. Gasser, I. Ott, N. Metzler-Nolte, Organometallic Anticancer Compounds, J. Med. Chem., 54 (2011), 3-25.

[6] Z. Liu, L. Salassa, A. Habtemariam, A.M. Pizarro, G.J. Clarkson, P.J. Sadler, Contrasting reactivity and cancer cell cytotoxicity of isoelectronic organometallic iridium(III) complexes, Inorg. Chem., 50 (2011), 5777-5783.

[7] M. Dörr, E. Meggers, Metal complexes as structural templates for targeting proteins, Curr. Opin. Chem. Biol., 19 (2014) 76-81.

[8] K.K.W. Lo, Luminescent rhenium(I) and iridium(III) polypyridine complexes as 
biological probes, imaging reagents, and photocytotoxic agents, Acc. Chem. Res., 48 (2015), 2985-2995.

[9] J. Ruiz, V. Rodríguez, N. Cutillas, K.G. Samper, M. Capdevila, Ò. Palacios, A. Espinosa, Novel C,N-chelate rhodium(III) and iridium(III) antitumor complexes incorporating a lipophilic steroidal conjugate and their interaction with DNA, Dalton Trans., 41 (2012), 12847-12856

[10] M. Grasa, Bruno Therriena, G. Süss-Finka, A. Casinib, F. Edafeb, P.J. Dyson, Anticancer activity of new organo-ruthenium, rhodium and iridium complexes containing the 2-(pyridine-2-yl)thiazole N,N-chelating ligand, J. Organomet. Chem., 695 (2010) 1119-1125.

[11] H. Amouri, J. Moussa, A.K. Renfrew, P.J. Dyson, M.N. Rager, L.M. Chamoreau. Discovery, structure, and anticancer activity of an iridium complex of diselenobenzoquinone, Angew. Chem., 122 (2010), 7692-7695; Angew. Chem. Int. Ed., 49 (2010), 7530-7533.

[12] J.M. Hearn, I. Romero-Canelón, B. Qamar, Z. Liu, I. Hands-Portman, P.J. Sadler, Organometallic iridium(III) anticancer complexes with new mechanisms of action: NCI-60 Screening, mitochondrial targeting, and apoptosis, ACS Chem. Biol., 8 (2013), 1335-1343.

[13] Z. Liu, P.J. Sadler, Organoiridium Complexes: Anticancer Agents and Catalysts, Acc. Chem. Res., 47 (2014), 1174-1185.

[14] E. Meggers, Exploring biologically relevant chemical space with metal complexes, Curr. Opin. Chem. Biol., 11 (2007) 287-292. 
[15] Z. Liu, I. Romero-Caneln, B. Qamar, J.M. Hearn, A. Habtemariam, N.P.E. Barry, A.M. Pizarro, G.J. Clarkson, P.J. Sadler, The potent oxidant anticancer activity of organoiridium catalysts, Angew. Chem. Int. Ed., 53 (2014), 3941-3946.

[16] Y. Li, C.P. Tan, W. Zhang, L. He, L.N. Ji, Z.W. Mao, Phosphorescent iridium(III)-bis-N-heterocyclic carbene complexes as mitochondria-targeted theranostic and photodynamic anticancer agents, Biomaterials, 39 (2015) 95-104.

[17 C. Bach, H. Willner, C.Q Wang, S.J. Rettig, J. Trotter, F. Aubke, Cationic Iridium(III) Carbonyl Complexes: $\left[\operatorname{Ir}(\mathrm{CO})_{6}\right]^{3+}$ and $\left[\operatorname{Ir}(\mathrm{CO})_{5} \mathrm{Cl}\right]^{2+}$, Angew. Chem. Int. Ed., 35 (1996) 1974-1976.

[18] A. Kastl, A. Wilbuer, A.L. Merkel, L. Feng, P.D. Fazio, M. Ocker, E. Meggers, Dual anticancer activity in a single compound: visible-light-induced apoptosis by an antiangiogenic iridium complex, Chem. Commun., 48 (2012), 1863-1865.

[19] K. Henze, W. Martin, Essence of mitochondria, Nature, 426 (2002), 127-128.

[20] H.M. McBride, M. Neuspiel, S. Wasiak, Mitochondria: more than just a powerhouse. Curr. Biol. 16 (2006), R551-560.

[21] R.J. Youle, D.P. Narendra, Mechanisms of mitophagy, Nat. Rev. Mol. Cell. Biol., 12 (2011), 9-14.

[22] Y. Chen, L.P. Qiao, B.L. Yu, G.Y. Li, C.Y. Liu, L.N. Ji, H. Chao, Mitochondria-specific phosphorescent imaging and tracking in living cells with an AIPE-active iridium(III) complex, Chem. Commun., 49 (2013), 11095-11097.

[23] Y. Chen, L.P. Qiao, L.N. Ji, H. Chao, Phosphorescent iridium(III) complexes as multicolor probes for specific mitochondrial imaging and tracking, Biomaterials, 35 
(2014), 2-13.

[24] C.Z Jin, J.P. Liu, Y. Chen, L.L. Zeng, R.L. Guan, C. Ouyang, L.N. Ji, H. Chao, Cyclometalated iridium(III) complexes as two-photon phosphorescent probes for specific mitochondrial dynamics tracking in living cells, Chem. Eur. J., 21 (2015), 12000-12010.

[25] K.Q Qiu, H.Y. Huang, B.Y. Liu, Y.K Liu, P.Y. Zhang, Y. Chen, L.N. Ji, H. Chao, Mitochondria-specific imaging and tracking in living cells with two-photon phosphorescent iridium(III) complexes, J. Mater. Chem. B, 3 (2015), 6690-6697.

[26] Y. Chen, W.C. Xu, J.R. Zuo, L.N. Ji, H. Chao, Dinuclear iridium(III) complexes as phosphorescent trackers to monitor mitochondrial dynamics, J. Mater. Chem. B, 3 (2015), 3306-3314.

[27] X. Chen, L.L. Sun, Y. Chen, X.L. Cheng, W.J. Wu, L.N. Ji, H. Chao, A fast and selective two-photon phosphorescent probe for the imaging of nitric oxide in mitochondria, Biomaterials, 58 (2015), 72-81.

[28] Y. Chen, W.C. Xu, J.F. Kou, B.L. Yu, X.H. Wei, H. Chao, L.N. Ji, Aggregation-induced emission of ruthenium(II) polypyridyl complex $\left[\mathrm{Ru}(\mathrm{bpy})_{2}(\mathrm{pzta})\right]^{2+}$, Inorg. Chem. Commun., 13 (2010), 1140-1143.

[29] Y. Chen, W.C. Xu, J.F. Kou, B.L. Yu, X.H. Wei, B.L. Yu, H. Chao, L.N. Ji, Synthesis, crystal structures, electrochemical and spectroscopic properties of ruthenium(II) complexes containing diamino-1,3,5-triazine derivatives, Sci. China Chem., 53 (2010), 2009-2015.

[30] M. Nonoyama, Benzo[H]quinolin-10-yl-N iridium (III) complexes, B. Chem. Soc. 
Jpn., 47 (1974), 767-768..

[31] R. Blessing An empirical correction for absorption anisotropy, Acta. Crystallogr. Sect. A., 3 (1995), 33-38

[32] G.M. Sheldrick, SHELXS 97, program for X-ray crystal structure determination, University of Göttingen; 1997. SHELXL-97, Program for X-Ray Crystal Structure Refinement, University of Göttingen, 1997.

[33] A.E. Egger, C. Rappel, M.A. Jakupec, C.G. Hartinger, P. Heffeter, B.K. Keppler, Development of an experimental protocol for uptake studies of metal compounds in adherent tumor cells, J. Anal. Spectrom., 24 (2009), 51-61.

[34] C.Y. Li, Y. Liu, Y.Q. Wu, Y. Sun, F.Y. Li, The cellular uptake and localization of non-emissive iridium(III) complexes as cellular reaction-based luminescence probes, Biomaterials, 34 (2013), 1223-1234.

[35] L.L Zeng, Y. Chen, H.Y. Huang, J.Q. Wang, D.L. Zhao, L.N. Ji, H. Chao, Cyclometalated ruthenium(II) anthraquinone complexes exhibit strong anticancer activity in hypoxic tumor cells, Chem. Eur. J., 21 (2015), 15308-15319.

[36] H.Y. Huang, B.L. Yu, P.Y. Zhang, J.J. Huang, Y. Chen, G. Gasser, L.N. Ji, H. Chao, Highly charged ruthenium(II) polypyridyl complexes as lysosome-localized photosensitizers for two-photon photodynamic therapy, Angew. Chem. Int. Ed., 54 (2015), 14049-14052.

[37] R. Menicagli, S. Samaritani, G. Signore, F. Vaglini, L.D. Via, In vitro cytotoxic activities of 2-alkyl-4,6-diheteroalkyl-1,3,5-triazines: new molecules in anticancer research, J. Med. Chem., 47 (2004), 4649-4652. 
[38] B.B. Liu, T.M. Sun, Z.X. Zhou, L. Du, A systematic review on antitumor agents with 1, 3, 5-triazines, Med. chem., 5 (2015), 131-148.

[39] Z. Brzozowski, F. Sączewski, M. Gdaniec, Synthesis, structural characterization and antitumor activity of novel 2,4-diamino-1,3,5-triazine derivatives, Euro. J. Med. Chem., 35 (2000), 1053-1064.

[40] N. Baindur, N. Chadha, B.M. Brandt, D. Asgari, R.J. Patch, C. Schalk-HiHi, T.E. Carver, I.P. Petrounia, C.A. Baumann, H.Ott, C. Manthey, B.A. Springer, M.R. Player, 2-Hydroxy-4,6-diamino-[1,3,5]triazines: a novel class of VEGF-R2 (KDR) tyrosine kinase inhibitors, J. Med. Chem., 48 (2005), 1717-1720.

[41] K. Kamińska, J. Ziemba, J. Ner, J.S. Schwed, D. Łażewska, M. Więcek, T. Karcz, A. Olejarz, G. Latacz, K. Kuder, T. Kottke, M. Zygmunt, J. Sapa, J. Karolak-Wojciechowska, $\quad$ H. $\quad$ Stark, $\quad$ K. Kieć-Kononowicz, (2-Arylethenyl)-1,3,5-triazin-2-amines as a novel histamine H4 receptor ligands, Euro. J. Med. Chem., 103 (2015), 238-251.

[42] F.H. Case, The preparation of diazine derivatives containing the ferroin group, J. Heterocycl. Chem., 5 (1968), 223-226.

[43] F. Neve, M.L. Deda, A. Crispini, A. Bellusci, F. Puntoriero, S. Campagma, Cationic cyclometalated iridium luminophores: photophysical, redox, and structural characterization. Organometallics, 23 (2004), 5856-5863.

[44] A. Habtemariam, M. Melchart, R. Fernandez, S. Parsons, I.D. Oswald, A. Parkin, F.P. Fabbiani, J.E. Davidson, A. Dawson, R.E. Aird, D.I. Jodrell, P.J. Sadler, Structure-activity relationships for cytotoxic ruthenium(II) arene complexes 
containing N, N-, N, O-, and O, O-chelating ligands, J. Med. Chem. 49 (2006), $6858-6868$.

[45] H.Y. Huang, P.Y. Zhang, B.L. Yu, Y. Chen, J.Q. Wang, L.N. Ji, H. Chao, Targeting nucleus DNA with a cyclometalated dipyridophenazineruthenium(II) complex, J. Med. Chem., 57 (2014), 8971-8983.

[46] H.Y. Huang, P.Y. Zhang, H.M. Chen, L.N. Ji, H. Chao, Comparison between polypyridyl and cyclometalated ruthenium(II) complexes: anticancer activities against 2D and 3D cancer models, Chem. Eur. J., 21 (2015), 715-725.

[47] I. Vermes, C. Haanen, H. Steffens-Nakken, C. Reutelingsperger, A novel assay for apoptosis flow cytometric detection of phosphatidylserine expression on early apoptotic cells using fluorescein labelled Annexin V, J. Immunol. Methods, 184 (1995), 39-51.

[48] X.X. Yang, L.M. Chen, Y.N. Liu, Y.G. Yang, T.F. Chen, W.J. Zheng, J. Liu, Q.Y. He, Ruthenium methylimidazole complexes induced apoptosis in lung cancer A549 cells through intrinsic mitochondrial pathway, Biochimie, 94 (2012), 345-353.

[49] G.A. Piazza, A.K. Rahm, T.S. Finn, B.H. Fryer, H. Li, A.L. Stoumen, R. Pamukcu, D.J. Ahnen, Apoptosis primarily accounts for the growth-inhibitory properties of sulindac metabolites and involves a mechanism that is independent of cyclooxygenase inhibition, cell cycle arrest, and p53 induction, Cancer Res., 57 (1997), 2452-2459.

[50] A.J. Wagner, J.M. Kokontis, N. Hay, Myc-mediated apoptosis requires wild-type p53 in a manner independent of cell cycle arrest and the ability of p53 to induce 
p21waf1/cip1, Genes Dev., 8 (1994), 2817-2830. 


\section{Figure captions:}

Fig. 1 Chemical structures of complexes Ir1-Ir4.

Fig. 2 ORTEP diagrams of the Ir(III) complexes Ir3. For clarity, the solvent molecules, the hydrogen atoms, and the counter anions are omitted.

Fig. 3 ICP-MS quantification of the internalized iridium by the A549R and LO2 cells. Cells were treated with $2.5 \mu \mathrm{M}$ of Ir1-Ir4 at $37^{\circ} \mathrm{C}$ for $6 \mathrm{~h}$.

Fig. 4 The cellular uptake mechanism study. A549R cells (a) and LO2 cells (b) were pretreated with $50 \mathrm{mM}$ 2-deoxy-D-glucose and $5 \mu \mathrm{M}$ oligomycin in serum-free DMEM for $1 \mathrm{~h}$ before incubation of $2.5 \mu \mathrm{M}$ Ir1-Ir4 with inhibitor in the fresh media for $6 \mathrm{~h}$ at $4{ }^{\circ} \mathrm{C}$ or $37^{\circ} \mathrm{C}$, then collected and analyzed using ICP-MS.

Fig. 5 (a) Histograms of A549R cells stained with annexin V-FITC conjugate after treatment with $2.5 \mu \mathrm{M}$ Ir1-Ir4 for $24 \mathrm{~h}$. FITC fluorescence was analysed in the FL1 channel with excitation at $488 \mathrm{~nm}$ and emission at $530 \pm 15 \mathrm{~nm}$. (b) A549R cells were treated with Ir1-Ir4 (2.5 $\mu \mathrm{M})$ for $24 \mathrm{~h}$, then collected and cell cycle was analyzed using flow cytometry. Apoptotic cells were calculated by measuring the area of the sub-G1 peak.

Fig. 6 The Effects of Ir1-Ir4 on the mitochondrial membrane potential. Cells were treated with $2.5 \mu \mathrm{M}$ Ir1-Ir4 for $24 \mathrm{~h}$, stained with JC-1 dye, and analysed by flow cytometry. Red fluorescence: hyperpolarized mitochondria; green fluorescence: depolarized mitochondria.

Fig. 7 (a) A549R cells were treated with $2.5 \mu \mathrm{M}$ Ir1-Ir4 for $24 \mathrm{~h}$. Caspase-9, caspase-3/7 activity and intracellular ROS expressed as the relative fluorescence intensities measured using a microplate reader; (b) Attenuating the ROS levels by tiron (5 mM) and NAC (10 mM) reduced the apoptosis population upon treatment with $2.5 \mu \mathrm{M}$ Ir1-Ir4 
for $24 \mathrm{~h}$. 
Table 1. $\mathrm{IC}_{50}$ values for the tested compounds toward various cell lines. ${ }^{a}$

\begin{tabular}{|c|c|c|c|c|c|c|}
\hline \multirow{2}{*}{ Origin } & \multirow{2}{*}{ Cell Line } & \multicolumn{5}{|c|}{$\mathrm{IC}_{50}(\mu \mathrm{M})$} \\
\hline & & Ir1 & Ir2 & Ir3 & Ir4 & cisplatin \\
\hline Breast & MCF-7 & $14.6 \pm 1.0$ & $12.1 \pm 1.2$ & $12.6 \pm 0.9$ & $4.61 \pm 0.5$ & $22.8 \pm 4.2$ \\
\hline \multirow[t]{2}{*}{ Lung } & A549 & $17.5 \pm 1.2$ & $10.1 \pm 0.7$ & $9.53 \pm 0.5$ & $2.77 \pm 0.2$ & $16.5 \pm 2.5$ \\
\hline & NCI-H460 & $16.4 \pm 1.7$ & $13.4 \pm 1.2$ & $15.4 \pm 0.8$ & $5.64 \pm 0.3$ & $22.1 \pm 1.7$ \\
\hline Liver & HepG2 & $19.0 \pm 1.3$ & $8.79 \pm 0.5$ & $9.41 \pm 0.7$ & $1.93 \pm 0.3$ & $18.7 \pm 2.1$ \\
\hline Cervix & HeLa & $8.68 \pm 0.4$ & $6.44 \pm 0.3$ & $5.96 \pm 0.3$ & $0.86 \pm 0.1$ & $20.2 \pm 3.6$ \\
\hline Colorectal & НСТ-116 & $13.2 \pm 1.6$ & $8.37 \pm 0.6$ & $9.11 \pm 1.2$ & $2.46 \pm 0.3$ & $14.7 \pm 2.3$ \\
\hline
\end{tabular}


Figure 1

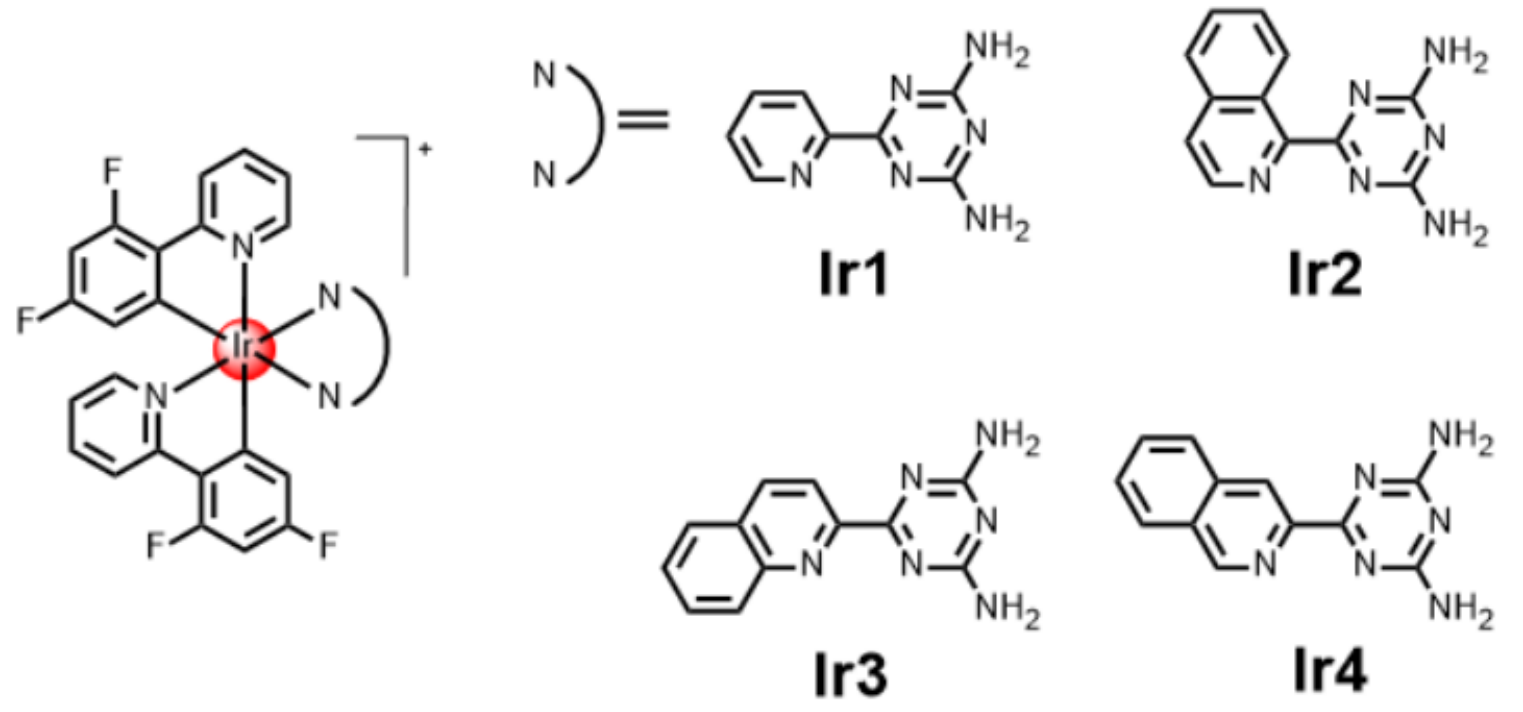


Figure 3

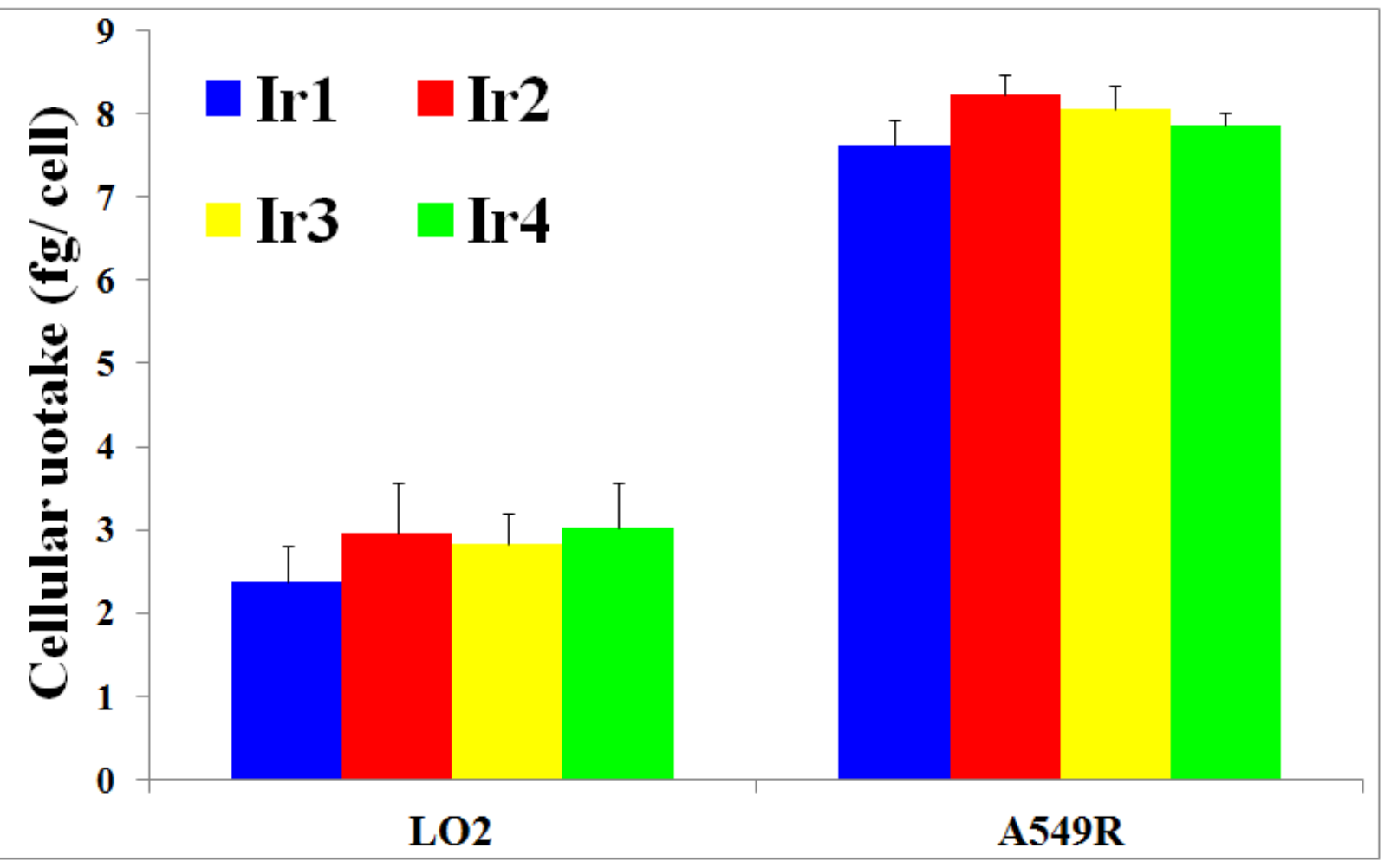


Figure 4

A549R

low temperature

metabolic inhibition

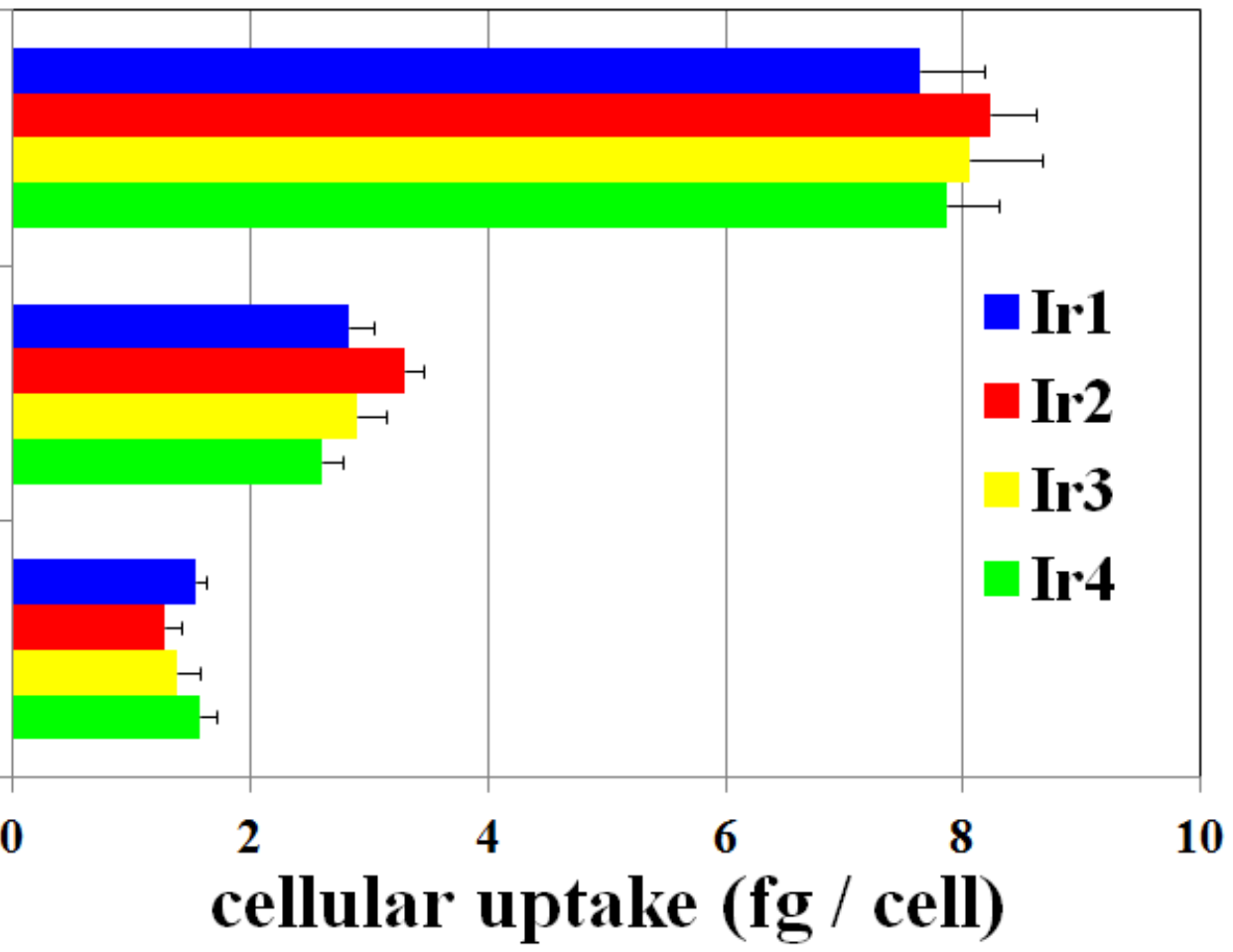

low temperature

metabolic inhibition

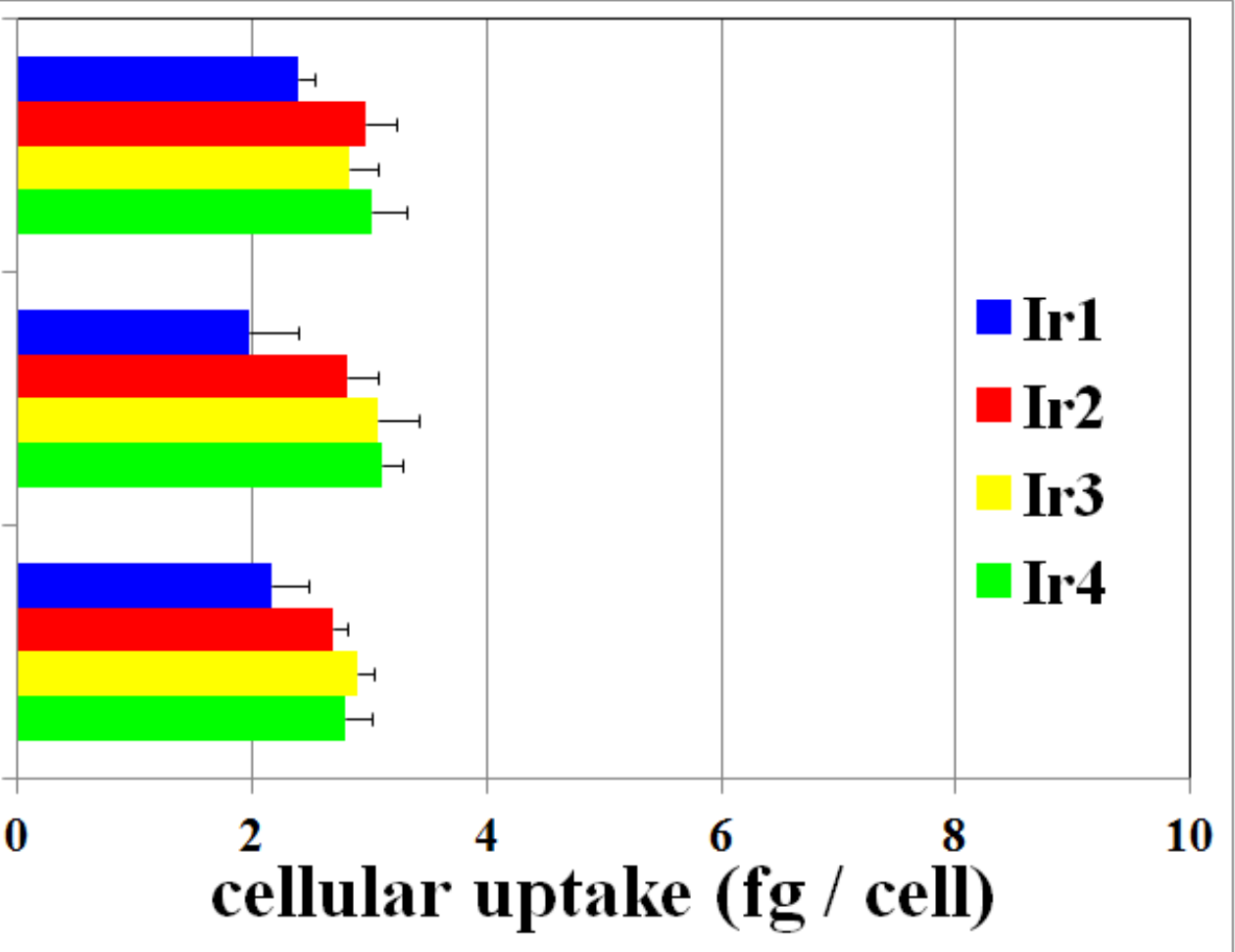


Figure 5

(a)
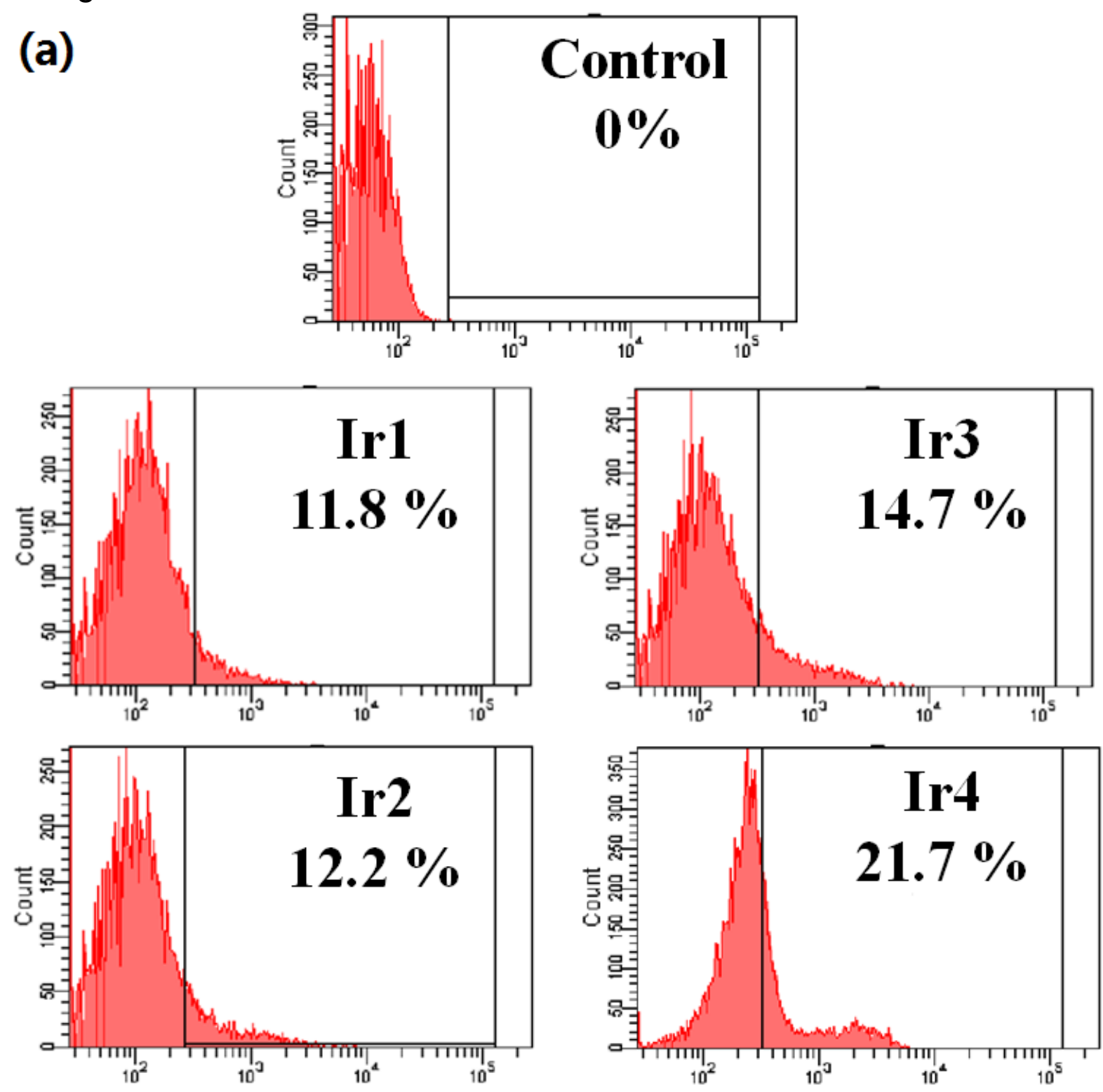

(b)

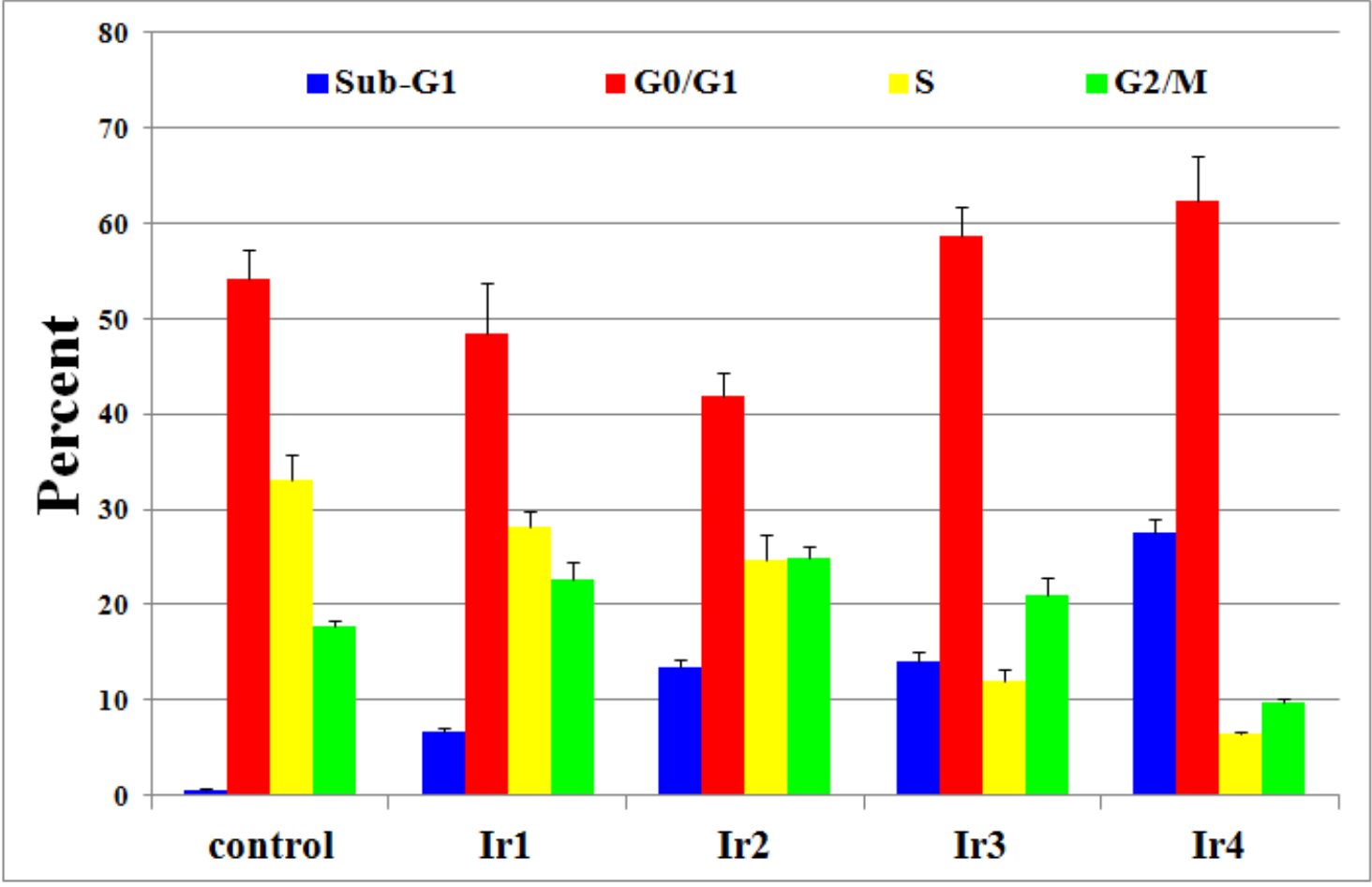


Figure 6
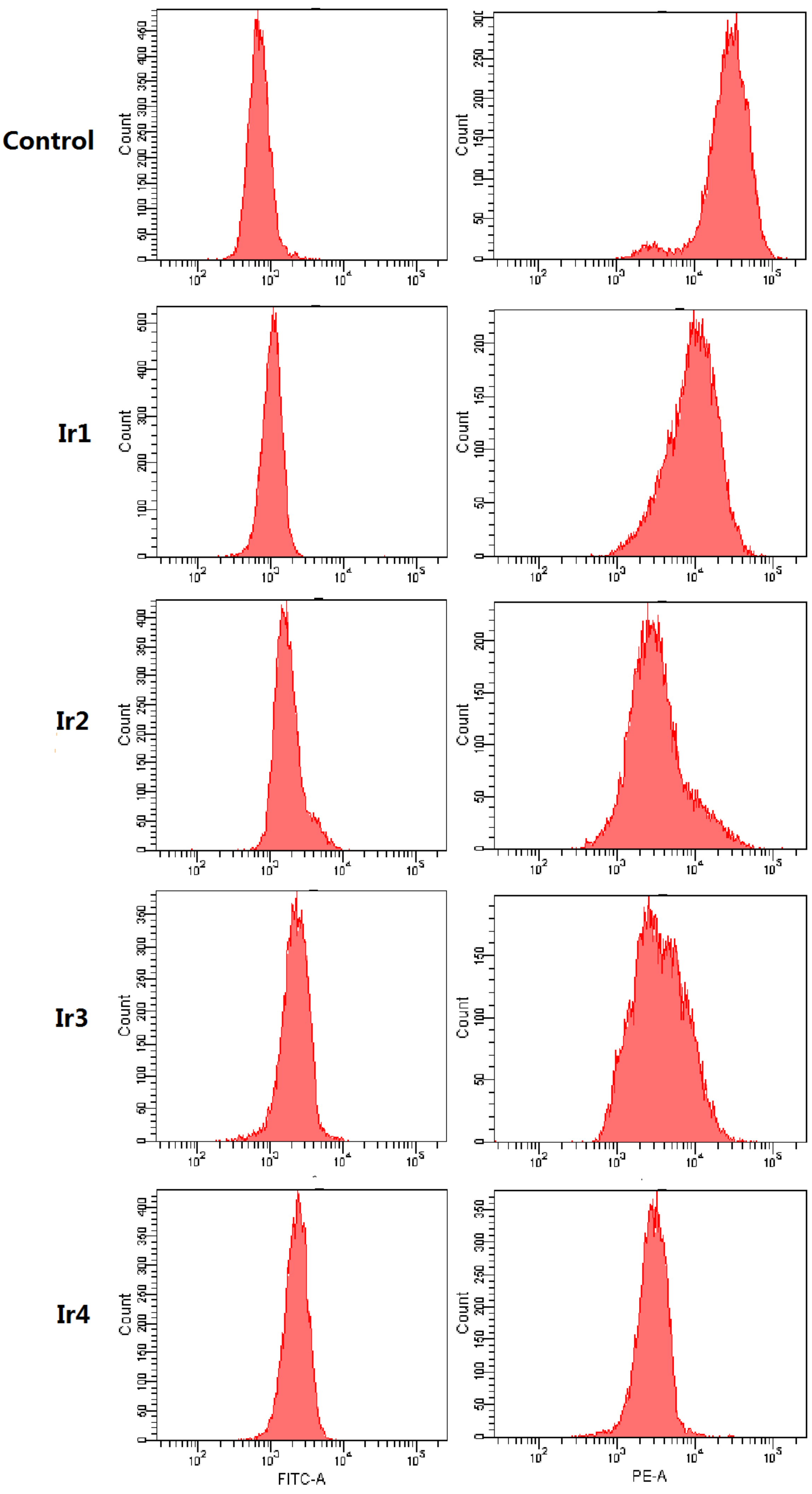
Figure 7

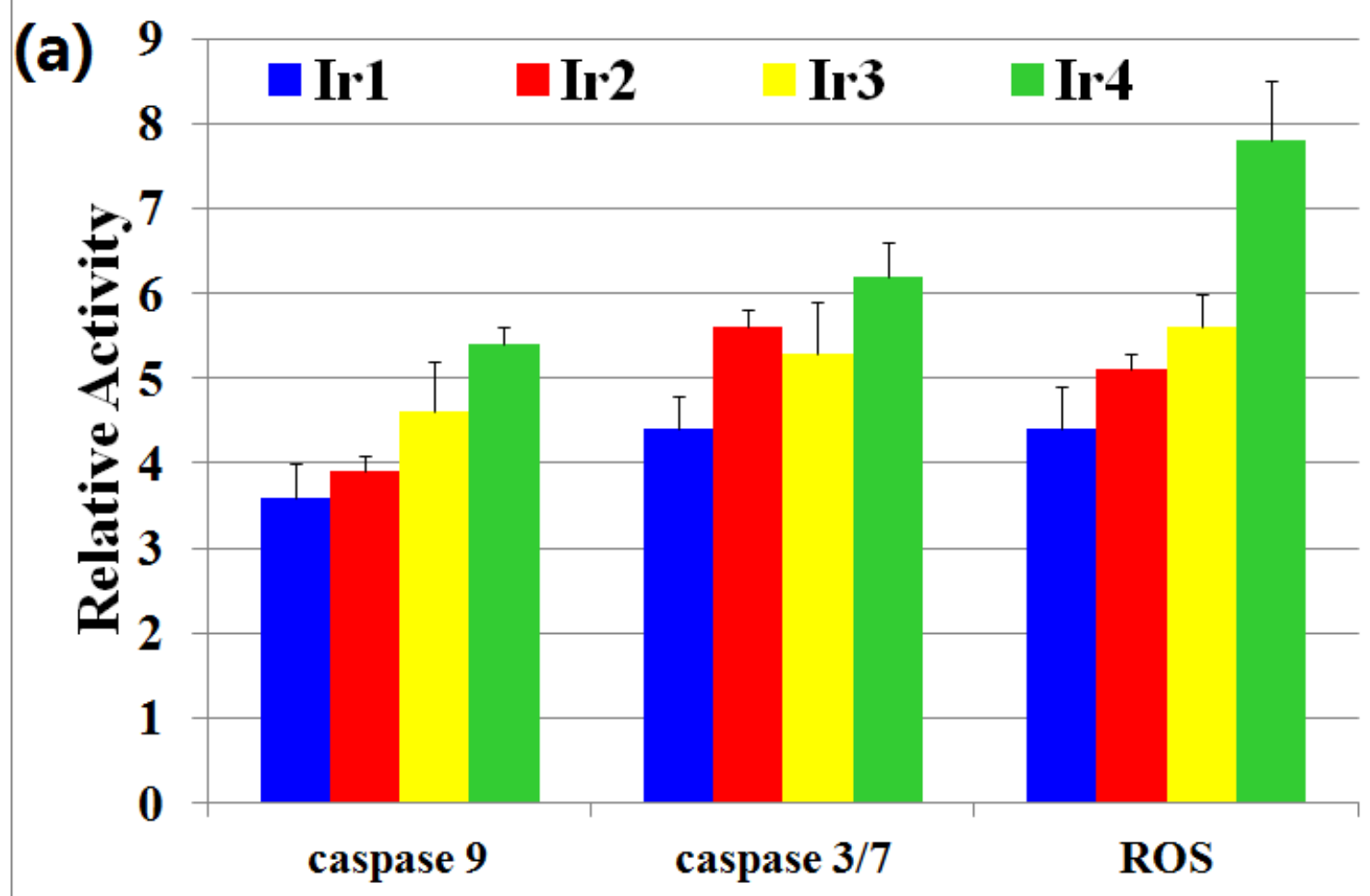

(b) 25

$\hat{\theta}^{20}$

715

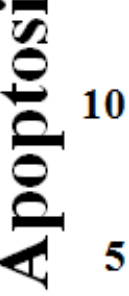

0 